\title{
Leptin and Cerulenin Differently Regulate Adiponectin Gene Expression in Chicken Liver and Hypothalamus
}

Petra Sintubin¹, Eddy Decuypere ${ }^{1}$, Johan Buyse ${ }^{1}$, Arieh Gertler $^{2}$ Rebekah Whitfield $^{3}$ and Sami Dridi',4*

${ }^{1}$ Laboratory of Physiology, Immunology, and Genetics of Domestic Animals, KU Leuven, 3001 Heverlee, Belgium.

${ }^{2}$ Institute of Biochemistry, Food Science and Nutrition, Faculty of Agriculture, The Hebrew University, Rehovot 76100, Israel.

${ }^{3} 37$ Oak Hill Rd, Wayland, MA 01778

\begin{abstract}
Adiponectin and leptin are two adipocytokines originally found to be secreted mainly by white adipose tissue (AT) in mammals. They are involved in the control of energy homeostasis, body weight, lipid metabolism, and insulin sensitivity. The interplay between these two hormones was exclusively studied in mammals and yielded conflicting results. In birds, adiponectin and leptin are expressed not only in AT, but also in liver (for leptin) and in a wide range of tissues (for adiponectin). However, their physiological roles and relationship are still unknown. The aim of the present study was to investigate the effect of recombinant chicken leptin on adiponectin gene expression in three metabolically important tissues (liver, hypothalamus, and muscle). The effect of gender and cerulenin, the natural fatty acid synthase inhibitor which has been shown to share some molecular mediators with leptin, were also evaluated. Females exhibited significantly $(P<0.05)$ higher levels of adiponectin mRNA in muscle and the liver, but not in the hypothalamus compared to male broiler chickens. Regardless of gender, muscle was found to contain the highest amount of adiponectin mRNA followed by the liver and hypothalamus. Continuous infusion of leptin $(8 \mu \mathrm{g} /$ $\mathrm{kg} / \mathrm{h}$ ) for $6 \mathrm{~h}$ in 3 -wk-old broiler chickens significantly $(P<0.05)$ increased plasma leptin levels, reduced food intake, and downreglated adiponectin gene expression in liver and muscle compared to the control. Cerulenin treatment (15 $\mathrm{mg} / \mathrm{ml})$ at different times significantly $(P<0.05)$ reduced food intake. These changes were accompanied by significant $(P<0.05)$ upregulation of hepatic adiponectin gene expression. Hypothalamic and muscle adiponectin mRNA abundance however were significantly $(P<0.05)$ downregulated by cerulenin treatment compared to the control. Our data showed that adiponectin gene expression is regulated by gender, leptin, and cerulenin in a tissue-specific manner. It also suggests that cerulenin does not mimic leptin by downregulating hepatic adiponectin, however it does mimic it by reducing food intake.
\end{abstract}

\section{Keywords: Adiponectin; Leptin; Cerulenin; Gender; Chickens}

Abbreviations: Acrp: adipocyte complement related protein; Adipo-R: adiponectin receptor; AMPK: AMP-activated protein kinase; ANOVA: analyse of variance; ApM: adipose most abundant gene transcript; DMSO: dimethyl sulfoxide; GBP: gelatin-binding protein; GLUT: glucose transporter; QPCR: real-time quantitative PCR; RIA : radioimmunoassay; RPMI: Roswell park memorial institute medium

\section{Introduction}

Adipose tissue secrets a large number of physiologically active peptides that often share structural properties of cytokines and are therefore referred to collectively as "adipocytokines" or "adipokines" $[1,2]$. The discovery of one of these peptides, leptin, which is the product of the obese gene [3], along with the characterization of adiponectin [4], has renewed interest in the hormonal regulation of energy homeostasis.

Leptin is a $16 \mathrm{kDa}$ glycosylated protein of 146 amino acids produced predominantly by adipose tissue in mammals [3] and functions as a hormonal signaling mechanism for fat deposition. Mammalian adipocytes produce and secrete more leptin in the bloodstream as fat storage increases [5], signaling the brain via leptin receptor [6] and modulating the hypothalamic neuropeptide systems to suppress appetite and increase energy expenditure [6,7]. Mutations in the genes encoding leptin or the leptin receptor result in increased obesity and a hormonal deficit [6]. Leptin treatment decreases serum glucose and lipogenesis and stimulates lipid oxidation in rodents $[8,9]$. These actions are mediated primarily through neuronal targets in the hypothalamus and peripheral tissues [10].

Adiponectin, also named gelatin-binding protein 28 (GBP-28), adipocyte complement related protein 30 (Acrp30), adipose most abundant gene transcript 1 (apM1), or adipoQ [4,11-13], is a $30 \mathrm{kDa}$ adipocytokine hormone of 244 amino acids exclusively secreted from adipose tissue in mammals. Adiponectin consists of an $\mathrm{N}$-terminal collagenous domain and a C-terminal globular domain [14]. It circulates as low-molecular-weight dimers or trimers and highmolecular-weight complexes in mammalian plasma [14]. Adiponectin acts, via two specific receptors adipo-R1 and adipo-R2 [15], as an insulin-sensitizing hormone whose blood concentrations are reduced in obesity and type-2 diabetes [16]. Administration of recombinant adiponectin to rodents increases glucose uptake and fat oxidation in muscle, reduces fatty acid uptake and hepatic glucose production in liver, and improves whole-body insulin resistance [17]. Moreover, intracerebroventricular administration of adiponectin decreases body weight and increases energy expenditure in rodents [18].

Altogether, these data showed that leptin and adiponectin exert

*Corresponding author: Dr. Sami Dridi, University of Kentucky, College of Medicine, Bosomworth HSRB Rm 252, 1095 VA Drive, Lexington KY 40536, USA, Tel: 859-257-3902, Fax: 859-257-2317; E-mail: Sami.Dridi@uky.edu

Received September 09, 2011; Accepted October 25, 2011; Published October 28, 2011

Citation: Sintubin P, Decuypere E, Buyse J, Gertler A, Whitfield R, et al. (2011) Leptin and Cerulenin Differently Regulate Adiponectin Gene Expression in Chicken Liver and Hypothalamus. J Microbial Biochem Technol 3: 067-072. doi:10.4172/1948-5948.1000054

Copyright: ( $) 2011$ Sintubin P, et al. This is an open-access article distributed under the terms of the Creative Commons Attribution License, which permits unrestricted use, distribution, and reproduction in any medium, provided the original author and source are credited 
major metabolic properties and suggest a potential interplay between these adipocytokine hormones. These hypotheses drew the attention of many scientists and represented the focus of intense research efforts exclusively in several mammalian species $[19,20]$. Acute leptin treatment did not modify plasma adiponectin levels in humans [21]. Longer administration of leptin yielded conflicting results in rodents. Indeed, leptin treatment did not affect plasma adiponectin levels in lipoatrophic A-ZIP/F-1 mice [22] however, it increased adiponectin gene expression in normal rats [23] and adiponectin plasma levels in ob/ob mice [19]. Such studies are currently lacking in non-mammalian species. Therefore, the present study primary aimed to investigate the effect of recombinant chicken leptin on adiponectin gene expression in broiler chickens.

Natural fatty acid synthase inhibitor cerulenin and its synthetic analog C75 have been shown to affect food intake and energy expenditure in mammals similarly to leptin and adiponectin [24,25]. These products were found to share some molecular mediators with adipocytokine hormones, such as feeding-related hypothalamic neuropeptides for leptin [26,27], and AMPK signaling cascades for both leptin and adiponectin [28-32]. Thus, the secondary aim of this study was to explore the effect of cerulenin on the expression of adiponectin gene, in light of its similarities to leptin.

\section{Materials and Methods}

\section{Animals}

Experiments were conducted in accordance with the directives of the European community (86/609/EEC) on the care and use of laboratory animals and the experimental protocols were approved by the K.U. Leuven Ethical Committee for Animal Experiments.

Experiment 1. Adiponectin gene expression in male and female broiler chickens: Male and female broiler chickens (Avibel, HalleZoersel, Belgium) of 6 weeks of age (1765 and 2665g for female and male, respectively) were kept on a floor pen under a 14:10-h light-dark cycle. Chickens were allowed food $(12.6 \mathrm{MJ} / \mathrm{kg} ; 21.4 \%$ protein) and water ad libitum. Chickens were killed by cervical dislocation and three metabolically important tissues (liver, hypothalamus, and leg muscle, $\mathrm{n}=3$ for each gender) were removed and immediately snap frozen in liquid nitrogen and stored at $-80^{\circ} \mathrm{C}$ until use.

Experiment 2. Leptin treatment: One day-old male broiler chicks (Avibel, Halle-Zoersel, Belgium) were reared on a floor pen until two weeks of age, at which time the birds were transferred to individual cages and were fed ad libitum (12 MJ/kg; 22\% protein). After three days of adaptation, birds were weighed and cannulated in the brachial artery [66] under local anaesthesia (xylocaine). The chickens were allowed to recover and to adapt during four more days. Before the infusion experiment, the chickens were divided into two homogenous weight-matched groups ( $\mathrm{n}=5$, mean of body weight was $1000 \mathrm{~g})$ and food deprived for two hours in order to increase their appetite. The mini pump (Syringe pump series, Model 22, Harvard apparatus, Massachusetts, USA), infused recombinant chicken leptin [8 $\mu \mathrm{g} / \mathrm{kg} / \mathrm{h}$ )] or saline at constant rate of $3 \mathrm{~mL} / \mathrm{h}$ during six hours and food intake was recorded after the treatment (6h). Birds were killed by cervical dislocation and tissues (hypothalamus, liver and leg muscle) were removed and snap frozen in liquid nitrogen and stored at $-80^{\circ} \mathrm{C}$ until use.

Experiment 3. Cerulenin administration: One day-old broiler chickens (Avibel, Halle-Zoersel, Belgium) were reared on a floor pen until one week of age, at which time the birds were transferred to individual cages and provided with individual feeders and drinking nipples. Food (12 MJ/kg; 22\% protein) and water were consumed ad libitum and the lighting schedule provided $14 \mathrm{~h}$ of light per day. After one week of adaptation, birds were divided into two homogenous weight $(267 \mathrm{~g})$ and food intake matched groups $(\mathrm{n}=4)$, and food deprived for two hours in order to increase their appetite. Each bird received an intravenous (IV) injection (at 0,4 and $24 \mathrm{~h}$ ) of $15 \mathrm{mg} / \mathrm{kg}$ cerulenin (Sigma, Belgium) or equal volume of vehicle (10\% DMSO in RPMI 1640 medium). Cumulative food intake was measured after $28 \mathrm{~h}$ and tissues (hypothalamus, liver and leg muscle) were removed, frozen in liquid nitrogen and stored at $-80^{\circ} \mathrm{C}$ until use.

\section{Real-time Quantitative PCR (QPCR)}

Total RNA was extracted from $100 \mathrm{mg}$ of tissue using the Trizol reagent (Invitrogen, Belgium) according to the manufacturer's protocol and was treated with RQ1 RNAase-free DNase (Promega, Belgium). RNA integrity and quality were assessed via $1 \%$ agarose gel electrophoresis and RNA concentrations and purity were determined for each sample spectrophotometrically by using UV absorbance (260/280). Total RNA (1 $\mu \mathrm{g})$ was reverse transcribed as previously described [56] and subjected to QPCR. QPCR analyses were performed in ABI PRISM 7000 Sequence Detector apparatus (Applied Biosystems, Belgium) in the presence of $25 \mu \mathrm{l}$ master mix containing $25 \mathrm{ng}$ template cDNA, 2X Power SYBR GREEN PCR Master Mix (Applied Biosystems, Belgium), and $300 \mathrm{nM}$ forward and reverse primers (Invitrogen, Belgium). Oligonucleotide primers specific for chicken adiponectin [33] and standard housekeeping genes $\beta$-actin and ribosomal $18 \mathrm{~S}$ as internal controls were used (Table 1). The primers were selected and designed for optimal hybridization kinetics using the Primer Express Software (version 2, Applied Biosystems, CA, USA). The QPCR cycling conditions were: $50^{\circ} \mathrm{C}$ for $2 \mathrm{~min}, 95^{\circ} \mathrm{C}$ for $10 \mathrm{~min}$, followed by 40 cycles of two-step amplification program $\left(95^{\circ} \mathrm{C}\right.$ for $15 \mathrm{~s}$, and $59^{\circ} \mathrm{C}$ for $\left.1 \mathrm{~min}\right)$. At the end of amplification, melting curve analysis was applied to exclude the contamination of unspecific PCR products such as primer dimers using the dissociation protocol from the Sequence Detection System. Each sample was run in triplicate and the average threshold cycle $(\mathrm{Ct})$ values were determined for adiponectin, -actin and $18 \mathrm{~S}$. For negative controls, no RT products were used as template in the QPCR. Relative quantities of target adiponectin mRNA were estimated by the $2^{-\Delta \Delta C t}$ method [67]. For experiments 2 (leptin) and 3 (cerulenin), the untreated groups were chosen as the calibrators. For the first experiment (gender), male liver was arbitrarily chosen as the calibrator.

\section{Plasma leptin measurement}

Circulating leptin concentrations were determined by RIA (multispecies leptin RIA kit, Linco Research Co). The RIA has been validated

\begin{tabular}{|c|c|c|c|}
\hline Gene & $\begin{array}{l}\text { Accession } \\
\text { number }^{a}\end{array}$ & $\begin{array}{l}\text { Primer sequence }\left(5^{\prime} \rightarrow 3^{\prime} ; \text { forward, }\right. \\
\text { reverse) }\end{array}$ & Size (bp) \\
\hline Adiponectin & AY-523637 & $\begin{array}{l}\text { GCCAGGTCTACAAGGTGTCA } \\
\text { CCATGTGTCCTGGAAATCCT }\end{array}$ & 86 \\
\hline $18 S$ & AF-173612 & $\begin{array}{l}\text { ACGAGACTCTGGCATGCTAACTAGT } \\
\text { GCCACTTGTCCCTCTAAGAAGTTG }\end{array}$ & 74 \\
\hline$\beta$-actin & L08165 & $\begin{array}{l}\text { CTGGCACCTAGCACAATGAA } \\
\text { СTGCTTGCTGATCCACATCT }\end{array}$ & 123 \\
\hline
\end{tabular}


for chicken leptin [68]. Samples were assayed in a single assay and the intra-assay coefficient of variation was $6.3 \%$.

\section{Statistical analysis}

The data were analyzed by using the student's unpaired $t$-test, except for the data from experiment 1 , which were analyzed by twofactor ANOVA with tissue and gender as classification variables. If ANOVA revealed significant effects, the means were compared by Student-Newman-Keuls (SNK)'s multiple range test using the Graph pad software (version 3.02, 2000, San Diego, USA). Differences were considered significant at $\mathrm{P}<0.05$.

\section{Results}

\section{Adiponectin gene expression in male and female broiler} chickens

Female broiler chickens exhibited significantly $(\mathrm{P}<0.05)$ higher levels of adiponectin mRNA in the liver (1.6-fold) and muscle (2.4fold) compared to males (Figure 1). In contrast, hypothalamic adiponectin gene expression was similar for both genders. Independent of sex, muscle was found to contain the highest amount of adiponectin mRNA, followed by the liver and hypothalamus.

Effect of leptin on food intake, leptinemia, and adiponectin gene expression in broiler chickens

Continuous infusion of recombinant chicken leptin significantly $(\mathrm{P}<0.05)$ increased plasma leptin levels $(23$-fold, Figure $2 \mathrm{~A})$, and reduced food intake by $50 \%$ (Figure $2 \mathrm{~B}$ ) compared to the vehicletreated group. Recombinant chicken leptin significantly downregulated adiponectin gene expression in chicken liver and muscle by $81 \%$ and $63.5 \%$, respectively $(\mathrm{P}<0.05)$ compared to the vehicle-treated group (Figure 3). The slight decrease (9\%) of hypothalamic adiponectin mRNA levels after leptin treatment was not statistically discernable at the $5 \%$ level.

\section{Effect of cerulenin on food intake, leptinemia, and adiponectin gene expression in broiler chickens}

Cerulenin treatment slightly decreased plasma leptin levels (Figure $4 \mathrm{~A})$ and significantly reduced food intake $(22 \%, \mathrm{P}<0.05)$ compared to the vehicle-treated group (Figure 4B). These changes were accompanied by a significant upregulation $(2$-fold, $\mathrm{P}<0.05)$ of hepatic adiponectin

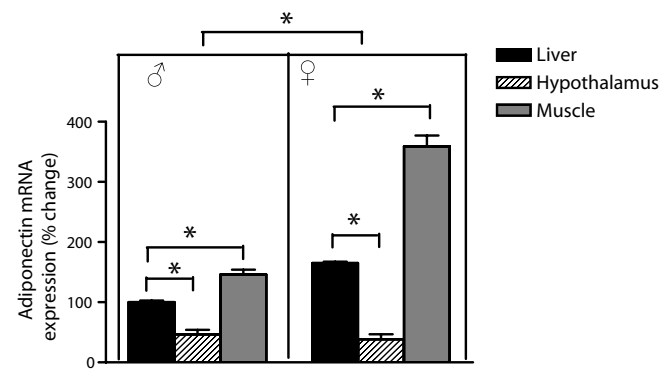

Figure 1: Relative quantity of adiponectin mRNA in liver, hypothalamus, and muscle of 6-wk-old male and female broiler chickens: Total RNA from each tissue was DNAse-treated, reverse transcribed and subjected to real-time quantitative PCR (QPCR) as described in materials and methods. Samples were run in triplicate and the average threshold cycle $(\mathrm{Ct})$ values were determined for adiponectin and housekeeping genes (18S and $\beta$-actin). Relative quantity of adiponectin mRNA was determined by the $2^{-\Delta \Delta C t}$ method [67]. Data are presented as mean \pm SEM ( $n=3$ for each gender and each tissue) and * represent significant difference at $\mathrm{P}<0.05$.
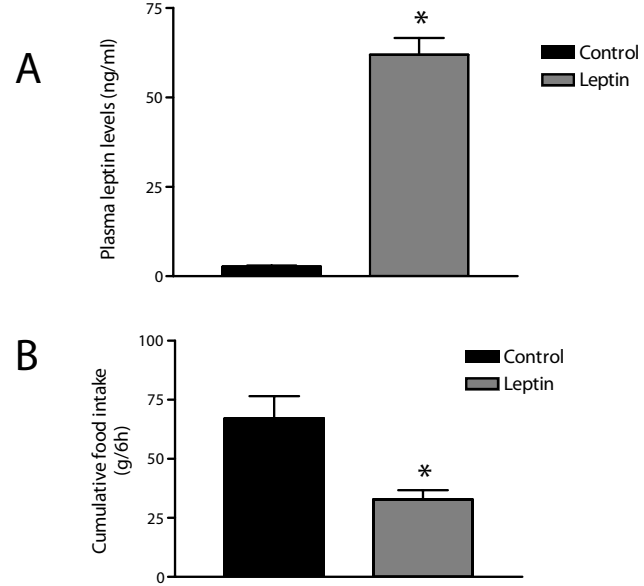

Figure 2: Effect of leptin treatment on plasma leptin levels (A) and cumulative food intake $(B)$ in broiler chickens: Two homogenous weightmatched groups of 3-wk-old broiler chickens $(n=5)$ were continuously treated with recombinant chicken leptin $(8 \mu \mathrm{g} / \mathrm{kg} / \mathrm{h}$ during $6 \mathrm{~h}$ at a constant rate of 3 $\mathrm{mL} / \mathrm{h}$ ) or saline solution. Food intake was recorded at the end of the treatment and plasma leptin levels were measured by RIA as described in materials and methods. Data are presented as mean \pm SEM and * different from the control, $\mathrm{P}<0.05$.

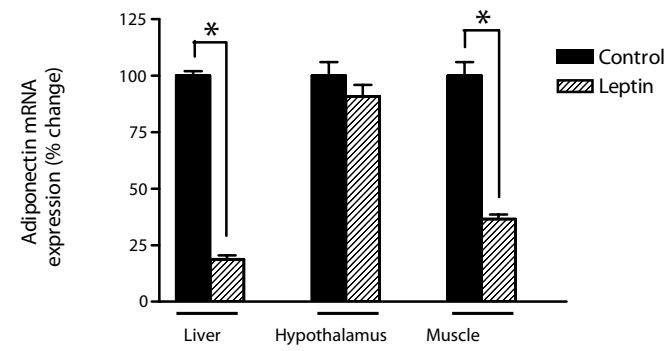

Figure 3: Effect of leptin treatment on adiponectin gene expression in broiler chickens: Two homogenous weight-matched groups of 3-wk-old broiler chickens $(n=5)$ were continuously treated with recombinant chicken leptin or saline solution. Birds were killed and total RNA was isolated from liver, hypothalamus, and muscle and subjected to RT-QPCR. Data are presented as mean \pm SEM. ${ }^{*} \mathrm{P}<0.05$ indicates a significant difference between leptin-treated group and the control.

gene expression, whereas hypothalamic and muscle adiponectin mRNA levels were significantly $(\mathrm{P}<0.05)$ decreased by $82 \%$ and $74 \%$ respectively, compared to the vehicle-treated group (Figure 5).

\section{Discussion}

Although adiponectin is expressed in a wide range of tissues in chickens [33], its hormonal regulation and physiological roles are still unknown. In the present study, we investigated the regulation of adiponectin gene expression by gender, leptin, and cerulenin in three metabolically important tissues; the hypothalamus (the main site for food intake and energy homeostasis control [34], the liver (the main site for de novo fatty acid synthesis, lipogenesis [35], and muscle (the main site for thermogenesis [36].

Muscle was found to contain the highest amount of adiponectin mRNA, followed by the liver and hypothalamus in 6-wk-old male and female broiler chickens. This result is quite different from that reported 
by Maddineni et al. [33] who have shown that adiponectin gene was highly expressed in the liver followed by the hypothalamus and muscle in 35-wk-old laying hens. It is not clear why such disparate results have been observed, but the use of tissues from different chicken strains (layer vs broiler) at different ages (6 vs 35 weeks) could contribute to these discrepancies. In fact, about 70 years of extensive selection for different performances, high meat yield for broilers and efficient egg production for layers, have resulted in two dramatically different strains of obese and lean phenotypes, respectively. These strains differ not only in food intake [37], growth rate [38] and fat accumulation, but also in behavioral [39] and neuroendocrine systems [40-43].

Interestingly, the hepatic and muscle expression of adiponectin gene is gender-dependent with higher levels in female compared to male chickens. This result is in agreement with previous studies in rodents and humans [44-47]. The underlying mechanism(s) for the apparent sexual dimorphic expression of adiponectin gene in chickens is (are)

A

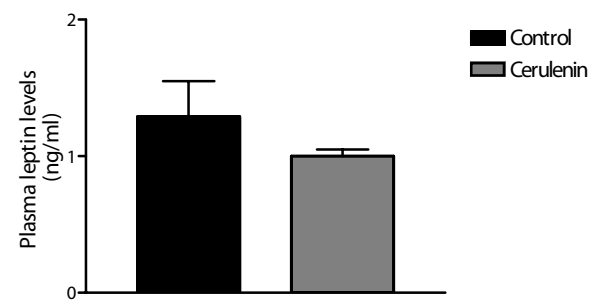

B

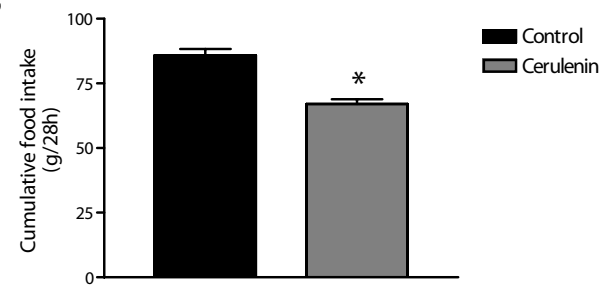

Figure 4: Effect of cerulenin treatment on plasma leptin levels (A) and cumulative food intake (B) in broiler chickens: Two homogenous weightmatched groups of 2-wk-old broiler chickens $(n=4)$ were intravenously treated with cerulenin $(15 \mathrm{mg} / \mathrm{kg}$ at 0,4 , and $24 \mathrm{~h}$ ) or RPMI medium as a control. Cumulative food intake was monitored after $28 \mathrm{~h}$ and plasma leptin levels were measured by RIA as described in materials and methods. Data are presented as mean \pm SEM and * different from the control, $P<0.05$.

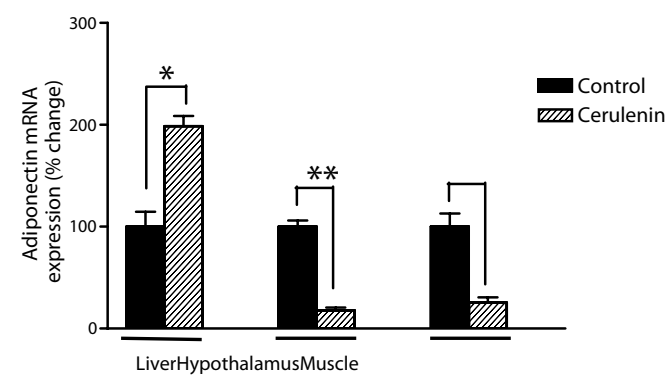

Figure 5: Effect of cerulenin treatment on adiponectin gene expression in broiler chickens: Two homogenous weight-matched groups of 2-wk-old broiler chickens $(n=4)$ were intravenously treated with cerulenin or RPMI medium as a control. Birds were killed and total RNA was isolated from liver, hypothalamus, and muscle and subjected to RT-QPCR. Data are presented as mean \pm SEM. ${ }^{*} \mathrm{P}<0.05$ indicates a significant difference between cerulenin-treated group and the control. unknown. It could be due to differences in fat deposition within tissues and/or levels of hormones, particularly sexual hormones. Indeed, ovariectomy significantly decreased adiponectin mRNA levels in mice and estrogen replacement increased adiponectin gene expression [44]. Testosterone administration reduced plasma adiponectin levels in both sham-operated and castrated male rats [48]. It is possible that other hormone systems known to be involved in lipid metabolism such as leptin, ghrelin, and growth hormone, can also influence the gender-dependent expression of avian adiponectin [49-51]. Sexspecific patterns of growth hormone secretion seem to be particularly important in sexually dimorphic gene expression in certain organs such as the liver [52]. In this situation, the trans-acting factor regulator of sex limitation (Rsl) functions to repress the transcription of a set of genes that have in common their induction by growth hormone in male liver [52].

The effect of leptin on the adiponectin system has recently been reported and the bulk of data were exclusively obtained from mammals $[19,20]$. To our knowledge, however, there is a paucity of information in non- mammalian species. The present study is the first to provide novel data on the regulation of adiponectin gene expression by leptin in broiler chickens. These strains were selected for rapid growth and high food intake, and are prone to obesity [53]. Chicken leptin is expressed not only in adipose tissue but also in the liver [54,55], and adiponectin is ubiquitously expressed in chickens [33], while these two adipocytokine genes are predominantly expressed in adipose tissues in mammals $[3,4]$. The mechanism of central action of leptin on food intake regulation in chickens is different from that described in mammals [56]. Furthermore, chickens are characteristically hyperglycemic, insulin resistant [57,58] and are lacking glucose transporter GLUT4 [59]. Taken together, these peculiarities suggest that chicken liver-derived leptin may exert different effects on adiponectin gene expression than that described in mammals. Our data showed that leptin regulates adiponectin gene expression in a tissue-specific manner with a down regulation in the liver and muscle, but not in the hypothalamus. This result confirms previous findings in human placenta [60], but it contrasts with previous data observed in rat adipose tissue [23]. The mechanism(s) behind these differences are not clear and may be related to many factors such as dose and time of leptin treatment, and tissueor species-specific effects.

Although leptin has long been known to play roles in the regulation of food intake and energy homeostasis, the potential role of fatty acid synthesis in this process has been considered only recently. Inhibition of fatty acid synthesis by cerulenin reduces food intake and induces profound reversible weight loss [24]. Centrally, this compound was hypothesized to alter, like leptin, the expression profiles of feedingrelated neuropeptides, often inhibiting the orexigenic and inducing the anorexigenic neuropeptide gene expression [27]. Therefore, in this study we sought to assess whether cerulenin affects, as does leptin, the avian adiponectin gene expression. Our data showed that in contrast to leptin, cerulenin treatment, at a dose that produces similar effects on food intake, upregulated adiponectin gene expression in chicken liver. However, the hypothalamic and muscle adiponectin mRNA levels were decreased by this treatment. Again, this result supports the notion of tissue-specific regulation of adiponectin gene and indicates that cerulenin does not act as leptin in the hepatic adiponectin system, although it does mimic some effects of leptin in the hypothalamus to reduce food intake [61]. The underlying molecular mechanism(s) of the divergent effects of leptin and cerulenin on the hepatic adiponectin gene expression is unclear. We speculate that it could be related to 
the leptin system itself since it has been suggested that leptin and adiponectin levels are inversely associated in mammals [62]. In our experimental conditions, cerulenin administration decreased plasma leptin levels to nearly $1 \mathrm{ng} / \mathrm{ml}$, however leptin treatment increased circulating leptin levels to $60 \mathrm{ng} / \mathrm{ml}$. Additionally, we have previously shown that in contrast to cerulenin, leptin treatment induces the chicken hepatic FAS gene expression [63], the key enzyme in fatty acid synthesis which catalyzes the synthesis of long-chain fatty acid synthesis through the condensation of acetyl-CoA and malonyl-CoA in a complex seven-step reaction [for review see [64]. Moreover, the avian liver is responsible for more than $90 \%$ of de novo fatty acid synthesis and is also a site of lipid storage in birds [35]. The negative association between adiponectin mRNA and fat pad size in rodents [65] supports our hypothesis, however further studies are clearly required to fully characterize the relationship between leptin, adiponectin and fatty acid synthesis in birds and their physiological roles in different avian tissues.

In rodents, it has been shown that changes in adiponectin gene expression were not always accompanied by concomitant changes in plasma adiponectin levels [19]. Because of limited quantities of tissues and unavailability of specific chicken adiponectin antibody we were not yet able to measure circulating adiponectin levels and protein content in different tissues in the present study.

In summary, we showed a sexually dimorphic expression of chicken adiponectin gene. Leptin and cerulenin differently regulate adiponectin in a tissue-specific manner. Further studies are warranted to fully understand the physiological roles of adiponectin and to shed light on its interaction with leptin and fatty acid synthesis in birds.

\section{Acknowledgments}

This work was supported by a research grant (G.0402.05) from the FWOFlanders (Belgium).

\section{References}

1. Mohamed-Ali V, Pinkney JH, Coppack SW (1998) Adipose tissue as an endocrine and paracrine organ. Int J Obesity 22: 1145-1158.

2. Guerre-Millo M (2002) Adipose tissue hormones. J Endocrinol Invest 25: 855861

3. Zhang Y, Proenca R, Maffei M, Barone M, Leopold L, et al. (1994) Positional cloning of the mouse obese gene and its human homologue. Nature (Lond) 372: 425- 432

4. Scherer PE, Williams S, Fogliano M, Baldini G, Lodish HF (1995) A nove serum protein similar to $\mathrm{C} 1 \mathrm{Q}$, produced exclusively in adipocytes. J Biol Chem 270: $26746-26749$

5. Maffei M, Halaas J, Ravussin E, Pratley RE, Lee GH, et al. (1995) Leptin levels in human and rodent: measurement of plasma leptin and ob RNA in obese and weight-reduced subjects. Nat Med 1: 1155-1161.

6. Friedman JM, Halaas $\mathrm{JL}$ (1998) Leptin and the regulation of body weight in mammals. Nature 395: 763-770.

7. Schwartz MW, Seeley RJ, Campfield LA, Burn P, Baskin DG (1996) Identification of targets of leptin action in rat hypothalamus. J Clin Invest 98: 1101-1106.

8. Lopez-Soriano J, Carbo N, Lopez-Soriano FJ, Argiles JM (1998) Short-term effects of leptin on lipid metabolism in the rat. FEBS Lett 431: 371-374.

9. Wang MY, Lee Y, Unger RH (1999) Novel form of lipolysis induced by leptin. J Biol Chem 274: 17541-17544.

10. Houseknecht KL, Portocarrero CP (1998) Leptin and its receptors: regulation of whole body energy homeostasis. Domest Anim Endocrinol 15: 457-475.

11. Nakano Y, Tobe T, Choi-Miura NH, Mazda T, Tomita M (1996) Isolation and characterization of GBP28, a novel gelatin-binding protein purified from human plasma. J Biochem (Tokyo) 120: 803-812.
12. Maeda K, Okubo K, Shimomura I, Funahashi T, Matsuzawa Y, et al. (1996) cDNA cloning and expression of a novel adipose specific collagen -like factor, apM1 (adipose most abundant gene transcript 1). Biochem Biophys Res Commun 221: 286-289.

13. Hu E, Liang P, Spiegelman BM (1996) AdipoQ is a novel adipose-specific gene dysregulated in obesity. J Biol Chem 271: 10697-10703.

14. Pajvani UB, Du X, Combs TP, Berg AH, Rajala MW, et al. (2003) Structurefunction studies of the adipocyte-secreted hormone Acrp30/diponectin. Implications for metabolic regulation and bioactivity. J Biol Chem 278: 90739085.

15. Yamauchi T, Kamon J, Ito Y, Tsuchida A, Yokomizo T, et al. (2003) Cloning of adiponectin receptors that mediate antidiabetic metabolic effects. Nature 423 762-769.

16. Zhu M, Miura J, Lu LX, Bernier M, Decabo R, et al. (2004) Circulating adiponectin levels increase in rats on caloric restriction: the potential for insulin sensitization. Exp Gerontol 39: 1049-1059.

17. Yamauchi T, Kamon J, Waki H, Terauchi Y, Kubota N, et al. (2001) The fatderived hormone adiponectin reverses insulin resistance associated with both lipoatrophy and obesity. Nat Med 7: 941-946.

18. Qi Y, Takahashi N, Hileman SM, Patel HR, Berg AH, et al. (2004) Adiponectin acts in the brain to decrease body weight. Nat Med 10: 524-529.

19. Delporte ML, El Mkadem SA, Quisquater M, Brichard SM (2004) Leptin treatment markedly increased plasma adiponectin but barely decreased plasma resistin of ob/ob mice. Am J Physiol 287: E446-E453.

20. Ueno N, Dube MG, Inui A, Kalra PS, Kalra SP (2004) Leptin modulates orexigenic effects of ghrelin and attenuates adiponectin and insulin levels and selectively the dark-phase feeding as revealed by central leptin gene therapy. Endocrinology 145: 4176-4184.

21. Gavrila A, Chan JL, Yiannakouris N, Kontogianni M, Miller LC, et al. (2003) Serum adiponectin levels are inversely associated with overall and central fat distribution but are not directly regulated by acute fasting or leptin administration in humans: cross-sectional and interventional studies. J Clin Endocrinol Metab 88: 4823-4831.

22. Colombo C, Cutson JJ, Yamauchi T, Vinson C, Kadowaki T, et al. (2002) Transplantation of adipose tissue lacking leptin is unable to reverse the metabolic abnormalities associated with lipoatrophy. Diabetes 51: 2727-2733.

23. Zhang Y, Matheny M, Zolotukhin S, Tumer N, Scarpace PJ (2002) Regulation of adiponectin and leptin gene expression in white and brown adipose tissue: influence of beta3-adrenergic agonists, retinoic acid, leptin and fasting. Biochim Biophys Acta 1584: 115-122

24. Loftus TM, Jaworsky DE, Frehywot GL, Townsend CA, Ronnett GV, et al. (2000) Reduced food intake and body weight in mice treated with fatty acid synthase inhibitors. Science 288: 2379-2381.

25. Jin YJ, Li SZ, Zhao ZS, An JJ, Kim RY, et al. (2004) Carnitine palmitoyltransferase-1 (CPT-1) activity stimulation by cerulenin via sympathetic nervous system activation overrides cerulenin's peripheral effect. Endocrinology 145: 3197-3204

26. Cha SH, Hu Z, Lane MD (2004) Long-term effects of a fatty acid synthase inhibitor on obese mice: food intake, hypothalamic neuropeptides, and UCP3. Biochem Biophys Res Commun 317: 301-308.

27. Shimokawa T, Kumar MV, Lane MD (2002) Effect of fatty acid synthase inhibitor on food intake and expression of hypothalamic neuropeptides. Proc Natl Acad Sci USA 99: 66-71.

28. Mobbs CV, Makimura H (2002) Block the FAS, lose the fat. Nat Med 8: 335336 .

29. Kim EK, Miller I, Aja S, Landree LE, Pinn M, et al. (2004) C75, a fatty acid synthase inhibitor, reduces food intake via hypothalamic AMP-activated protein kinase. J Biol Chem 279: 19970-19976.

30. Minokoshi Y, Alquier T, Furukawa N, Kim YB, Lee A, et al. (2004) AMP-kinase regulates food intake by responding to hormonal and nutrient signals in the hypothalamus. Nature 428: 569-574.

31. Minokoshi Y, Kim YB, Peroni O, Fryer LG, Muller C, et al. (2002) Leptin stimulates fatty-acid oxidation by activating AMP-activated protein kinase. Nature 415: 339-343. 
Citation: Sintubin P, Decuypere E, Buyse J, Gertler A, Whitfield R, et al. (2011) Leptin and Cerulenin Differently Regulate Adiponectin Gene Expression in Chicken Liver and Hypothalamus. J Microbial Biochem Technol 3: 067-072. doi:10.4172/1948-5948.1000054

32. Yamauchi T, Kamon J, Minokoshi Y, Ito Y, Waki H, et al. (2002) Adiponectin stimulates glucose utilization and fatty-acid oxidation by activating AMPactivated protein kinase. Nat Med 8: 1288-1295.

33. Maddineni S, Metzger S, Ocon O, Hendricks G, Ramachandran R (2005) Adiponectin gene is expressed in multiple tissues in the chickens: food deprivation influences adiponectin messenger ribonucleic acid expression. Endocrinology 146: 4250-4256.

34. Denbow DM (1985) Food intake control in birds. Neurosci Biobehav Rev 9: 223-232.

35. Leveille GA, Romsos DR, Yeh Y,O'Hea EK (1975) Lipid biosynthesis in the chick. A consideration of site of synthesis, influence of diet, and possible regulatory mechanisms. Poult Sci 54: 1075-1093.

36. Duchamp C, Barré H (1993) Skeletal muscle as the major site of nonshivering thermogenesis in cold-acclimated duckling. Am J Physiol 265: R10176-R10183.

37. Hen G, Yosefi S, Simchaev V, Shinder D, Hruby VJ, et al. (2006) The melanocortin circuit in obese and lean strains of chicks. J Endocrinol 190: 527535.

38. Hocking PM, Hughes BO, Keer-Keer S (1997) Comparison of food intake, rate of consumption, pecking activity and behaviour in layer and broiler breeder males. Br Poult Sci 38: 237-240.

39. Bokkers EA, Koene P (2003) Eating behaviour, and preprandial and postprandial correlations in male broiler and layer chickens. Br Poult Sci 44: 538-544

40. Saito S, Takagi T, Koutoku T, Saito ES, Hirakawa H, et al. (2004) Differences in catecholamine metabolism and behaviour in neonatal broiler and layer chicks. Br Poult Sci 45: 158-162.

41. Kuenzel WJ, Kuenzel NY (1977) Basal metabolic rate in growing chicks Gallus domesticus. Poult Sci 56: 619-627.

42. Tachibana T, Sugahara K, Ohgushi A, Ando R, Sashihara K, et al. (2001) Intracerebroventricular injection of exendin (5-39) increases food intake of layer-type chicks but not broiler chicks. Brain Res 915: 234-237.

43. Takagi T, Bungo T, Tachibana T, Saito CS, Saito S, et al. (2003) Intracerebroventricular administration of GABA-A and GABA-B receptor agonists attenuate feeding and sleeping-like behaviour induced by L-pipecolic acid in neonatal chicks. J Neurosci Res 73: 270-275.

44. Gui Y, Silha JV, Murphy LJ (2004) Sexual dimorphism and regulation of resistin, adiponectin, and leptin expression in the mouse. Obesity Res 12: 1481-1491.

45. Kern PA, Di Gregorio GB, Lu T, Rassouli N, Ranganathan G (2003) Adiponectin expression from human adipose tissue: relation to obesity, insulin resistance, and tumor necrosis factor-alpha expression. Diabetes 52: 1779-1785.

46. Yannakoulia M, Yiannakouris N, Bluher S, Matalas AL, Klimis-Zacas D, et al (2003) Body fat mass and macronutrient intake in relation to circulating soluble leptin receptor, free leptin index, adiponectin, and resisti concentrations in healthy humans. J Clin Endocrinol Metab 88: 1730-1736.

47. Combs TP, Berg AH, Rajala MW, Klebanov S, lyengar P, et al. (2003) Sexual differentiation, pregnancy, caloric restriction and aging affect the adipocytespecific secretory protein adiponectin. Diabetes 52: 268-276.

48. Nishizawa H, Shimomura I, Kishida K, Maeda N, Kuriyama H, et al. (2002) Androgens decrease plasma adiponectin and insulin-sensitizing adipocytederived protein. Diabetes 51: 2734-2741.

49. Kuhn ER, Darras VM, Gysemans C, Decuypere E, Berghman LR, et al. (1996) The use of intermittent lighting in broiler raising. Effects on the somatotrophic and thyroid axis and on plasma testosterone levels. Poult Sci 75: 595-600.

50. Richards MP, Ashwell CM, McMurtry JP (2000) Quantitative analysis of leptin mRNA using competitive reverse transcription polymerase chain reaction and capillary electrophoresis with laser-induced fluorescence detection. Electrophoresis 21: 792-798.

51. Liu YL, Yakar S, Otero-Corchon Y, Low MJ, Liu JL (2002) Ghrelin gene expression is age-dependent and influenced by gender and the level of circulating IGF-1. Mol Cell Endocrinol 189: 97-103.

52. Tullis KM, Krebs CJ, Leung JY, Robins DM (2003) The regular of sex-limitation gene, rsl, enforce male-specific liver gene expression by negative regulation. Endocrinology 144: 1854-1860.
53. Griffin HD, Goddard C (1994) Rapidly growing broiler (meat-type) chickens: their origin and use for comparative studies of the regulation of growth. Int $J$ Biochem 26: 19-28.

54. Ashwell CM, Czerwinski SM, Brocht DM, McMurtry JP (1999) Hormona regulation of leptin expression in broiler chickens. Am J Physiol 276 R226-R232.

55. Taouis M, Chen JW, Daviaud C, Dupont J, Derouet M, et al. (1998) Cloning the chicken leptin gene. Gene 208: 239-242.

56. Dridi S, Swennen Q, Decuypere E, Buyse J (2005) Mode of leptin action in chicken hypothalamus. Brain Res 1047: 214-223

57. Brady LJ, Romsos DR, Brady PS, Bergen WG, Leveille GA (1978) The effects of fasting on body composition, glucose turnover, enzymes and metabolites in the chicken. J Nutr 108: 648-657.

58. Simon J, Freychet P, Rosselin G (1977) A study of insulin binding sites in the chicken tissues. Diabetologia 13: 219-228.

59. Seki Y, Sato K, Kono T, Abe H, Akiba Y (2003) Broiler chickens (Ross strain) lack insulin-responsive glucose transporter GLUT4 and have GLUT8 cDNA Gen Comp Endocrinol 133: 80-87.

60. Chen J, Tan B, Karteris E, Zervou S, Digby J, et al. (2006) Secretion of adiponectin by human placenta: differential modulation of adiponectin and its receptors by cytokines. Diabetologia 49: 1292-1302.

61. Dridi S, Ververken C, Hillgartner FB, Arckens L, Van der Gucht E, et al. (2006) FAS inhibitor cerulenin reduces food intake and melanocortin receptor gene expression without modulating the other (an)orexigenic neuropeptides in chickens. Am J Physiol 291: R138-R147.

62. Wang SN, Yeh YY, Yu ML, Dai CY, Chi WC, et al. (2006) Hyperleptinaemia and hypoadiponectinaemia are associated with gallstone disease. Eur J Clin Invest 36: $176-180$

63. Dridi S, Buyse J, Decuypere E, Taouis M (2005) Potential role of leptin in increase of fatty acid synthase gene expression in chicken liver. Domest Anim Endocrinol 29: 646-660.

64. Smith S (1994) The animal fatty acid synthase: one gene, one polypeptide, seven enzymes. FASEB J 8: 1248-1259.

65. Florant GL, Porst H, Peiffer A, Hudachek SF, Pittman C, et al. (2004) Fat-cell mass, serum leptin and adiponectin changes during weight gain and loss in yellow-bellied marmots (Marmota flaviventris). J Comp Physiol B 174: 633-639.

66. Huybrechts LM, Decuypere E, Buyse J, Kuhn ER, Tixier-Boichard M (1992) Effect of recombinant human insulin-like growth factor-1 on weight gain, fat content, and hormonal parameters in broiler chickens. Poult Sci 71: 181-187.

67. Livak KJ, Schimittgen TD (2001) Analysis of relative gene expression data using real-time quantitative PCR and the $2^{-\triangle \Delta C t}$ method. Methods 25: 402-408.

68. Dridi S, Williams J, Bruggeman V, Onagbesan M, Raver N, et al. (2000) A chicken leptin-specific radioimmunoassay. Domest Anim Endocrinol 18: 325335 . 